https://nv.nltu.edu.ua

https://doi.org/10.36930/40310108

Article received $16.12 .2020 \mathrm{p}$.

Article accepted 04.02.2021 p.

$@ \bigotimes$ Correspondence author

H. B. Lukashchuk

UDC 712.2(091)(477.83)

\author{
halyna.lukashchuk@gmail.com
}

Г. П. Петришин, С. П. Тупісь, Я. О. Онуфрів, Г. Б. Лукащук

Національний університет "Львівська політехніка", м. Львів, Украӥна

\title{
ОБГРУНТУВАННЯ ПРИРОДНОЇ ЦІННОСТІ ТЕРИТОРІЇ "ДУБЛЯНСЬКОГО ПАРКУ" ДЛЯ НАДАННЯ СТАТУСУ ПАРКУ-ПАМ'ЯТКИ САДОВО-ПАРКОВОГО МИСТЕЦТВА
}

\begin{abstract}
Проаналізовано ландшафтну, планувальну, просторову структури "Дублянського парку" Самбірського району Львівської області. Встановлено, що на дослідженій території відсутні ознаки функціонального зонування, немає проєкту організації його території. Об'ємно-просторова структура цього парку, в основному, представлена закритим простором. Напіввідкриті простори виявлені вздовж русла річки Веретено та алеї біля північної межі парку. Переважає лісовий тип ландшафту, який виник на місці порушеного паркового ландшафту. Залишились окремі елементи регулярного парку у вигляді ділянки перерослого грабового боскету, які потребують реконструкції та збереження. Визначено основні види деревних і трав'яних рослин, що присутні на території, запропонованій для охорони у смт Дубляни Самбірського району. У дендрофлорі дослідженого парку більшість рослин належить до відділу Magnoliophyta. Видовий склад деревних рослин представлений 39 видами, які належать до 16 родин. Серед життєвих форм, які формують основу цього парку, переважають дерева (30 таксонів). Кущі представлені такими лісовими видами: Euonymus europaeus L., Cornus sanguinea L., Rosa canina L. У складі паркового фітоценозу смт Дубляни присутні інтродуковані вікові види, а саме: Juglans nigra L. та J. мandshurica Maxim,, Phellodendron amurense Rupr, Acer sacharinum L. та A. negundo L. За таких умов зростання для цих видів характерна досить висока стійкість, деякі з них дають природне поновлення, мають історичну та ботанічну цінність. У складі трав'яних рослин, здебільшого, переважають лісові види, що свідчить про відсутність належного догляду і витіснення штучних угруповань. Найвища частота трапляння та проєктивного вкриття спостерігається у Carex brizoides L., Stellaria holostea L., Aegopodium podagraria L., Pulmonaria obscura Dumort., Galeobdolon luteum Huds. Узагальнено назрілі проблеми функціонування досліджуваного парку, встановлено причини деградації зелених насаджень, намічено невідкладні природоохоронні та ландшафтно-планувальні завдання, обгрунтовано доцільність надання парку статусу парку-пам'ятки садово-паркового мистецтва місцевого значення у смт Дубляни Самбірського району Львівської області.
\end{abstract}

Ключові слова: парк-пам'ятка садово-паркового мистецтва; ландшафт; вікові дерева; дендрофлора; трав'яне вкриття.

\section{Вступ}

Гарантією збереження унікальних і типових природних ландшафтів, зменшення темпів втрати біорізноманіття є створення і підтримання науково обгрунтованої, репрезентативної, функціонально цілісної та ефективно керованої системи територій та об'єктів природно-заповідного фонду як базового елемента екологічно збалансованого соціально-економічного розвитку регіону у складі країни загалом.

Репрезентативна й функціонально цілісна мережа територій та об'єктів природно-заповідного фонду, створена $з$ урахуванням науково обгрунтованих підходів до збереження регіональної біотичної та ландшафтної різноманітності, $є$ структурно-функціональною основою формування екомережі як нової форми організації територіальної охорони природи в умовах подальшого інтенсивного антропогенного впливу на довкілля і тран- сформації природних ландшафтів $[4,20,29,30,31,32$, 33]. Згідно $з$ регіональною програмою розвитку заповідної справи у Львівській області на 2009-2020 рр., затвердженої рішенням Львівської обласної ради від 02.12.2008 р., № 765, пропонують створити на теритоpiï, що розташована в межах селища Дубляни Самбірського району Львівської області парк-пам'ятку садовопаркового мистецтва місцевого значення "Дублянський парк".

Об'єкт дослідження - територія, запропонована для створення об'єкта природно-заповідного фонду паркупам'ятки садово-паркового мистецтва місцевого значення на території смт Дубляни Самбірського району.

Предмет дослідження - ландшафтна, планувальна, просторова та флористична структури парку.

Мета роботи - обгрунтування природної цінності території для створення об'єкта природно-заповідного фонду: парку-пам'ятки садово-паркового мистецтва міс-

\section{Інформація про авторів:}

Петришин Галина Петрівна, канд. архітектури, професор, кафедра містобудування. Email: halyna.p.petryshyn@lpnu.ua Тупісь Степан Павлович, канд. архітектури, доцент, кафедра містобудування. Email: arhnovo@ukr.net

Онуфрів Ярина Олегівна, канд. архітектури, доцент, кафедра містобудування. Email: yarynaonufriv@gmail.com Лукащук Галина Богданівна, канд. с.-г. наук, доцент, кафедра містобудування. Email: halyna.lukashchuk@gmail.com

Цитування за ДСту: Петришин Г. П., Тупісь С. П., Онуфрів Я. О., Лукащук Г. Б. Обґрунтування природної цінності території "Дублянського парку" для надання статусу парку-пам'ятки садово-паркового мистецтва. Науковий вісник Нлту України. 2021, т. 31, № 1. С. 48-54.

Citation APA: Petryshyn, H. P., Tupis, S. P., Onufriv, Ya. O., \& Lukashchuk, H. B. (2021). Substantiation of the natural value of the "Dubliansky Park" territory in order to grant the status of a park - monument of garden and park art. Scientific Bulletin of UNFU, 31(1), 48-54. https://doi.org/10.36930/40310108 
цевого значення на території смт Дубляни Самбірського району.

Для досягнення зазначеної мети визначено такі основні завдання дослідження: встановити межі проєктованого парку-пам'ятки садово-паркового мистецтва місцевого значення на території у смт Дубляни Самбірського району; здійснити ландшафтно-просторовий аналіз території парку; визначити та охарактеризувати основні види деревних та трав'яних рослин, що ростуть на території, запропонованій для охорони; обгрунтувати доцільність створення парку-пам'ятки садово-паркового мистецтва місцевого значення на цій території.

Наукова новизна отриманих результатів дослідження - вперше досліджено важливий елемент культурного ландшафту Прикарпаття, визначено основні види деревних та трав'яних рослин, що ростуть на території, запропонованій для охорони у смт Дубляни Самбірського району, та обгрунтовано доцільність створення парку-пам'ятки садово-паркового мистецтва місцевого значення у смт Дубляни Самбірського району.

Практична значущість результатів дослідження узагальнено назрілі проблеми функціонування досліджуваного парку, встановлено причини деградації зелених насаджень, намічено невідкладні природоохоронні та ландшафтно-планувальні завдання, обгрунтовано доцільність надання парку статусу парку-пам'ятки садовопаркового мистецтва місцевого значення у смт Дубляни Самбірського району Львівської області.

Аналіз останніх досліджень та публікацій. Тематика досліджень історичних насаджень, надання їм охоронного статусу, питання проблем збереження біотичного і ландшафтного різноманіття $є$ актуальною для сталого розвитку всіх регіонів України. Багато досліджень стосуються ландшафтного та архітектурного аналізу історичних палацових комплексів та їх насаджень $[3,11,13,14,15,16,23]$. Деякі автори дали визначення типологічних особливостей, структури та об'ємно-просторового аналізу насаджень окремих регіональних парків із пропозицією напрямків використання та охорони цих територій $[2,8,19]$.

Питання екологічної мережі, охорони об'єктів природно-заповідного фонду та збереження його ландшафтного та біотичного різноманіття висвітлено в роботах Ю. О. Клименка [9], О. Г. Яворської [28], С. Ю. Поповича [17], С. П. Тупіся [25]. Загроза деградації зелених зон у структурі розселення зумовлює необхідність встановлення обмеження у видах діяльності та рівні допустимого навантаження на різні типи ландшафтів. Автори відзначають кардинальні зміни, що відбуваються з ландшафтами за відсутності системних заходів з утримання та охорони середовища. Комплексне функціонування заповідних територій сприяє вирішенню природоохоронних завдань, слугує об'єктом збереження цінних рослинних і ландшафтних композицій.

Основним нормативним документом, який регламентує заходи з утримання та охорони історичних насаджень, є Флорентійська Хартія Міжнародного комітету 3 історичних садів і ландшафтів (1981) [5], ратифікована Україною. Згідно з ії положеннями, історичний сад чи парк - це архітектурна і рослинна композиція, яка 3 точки зору історії або мистецтва становить суспільний інтерес. Вона потребує таких заходів, як охорона та утримання.
Матеріали та методи дослідження. У роботі використовували історичні та архівні джерела, картографічні матеріали, сучасні літературні джерела та наукові публікації. Інвентаризацію дендрофлори досліджуваної території здійснювали згідно з Інструкцією (Instrukcija, 2001). Таксономічний склад дендрофлори визначали на основі результатів польових обстежень маршрутним методом, який уточнювали за міжнародним списком "The Plant List" [24]. Розподіл за життєвими формами виконували за методикою I. Г. Серебрякова [22]. Стан вікових дерев оцінювали згідно з методикою С. Кузнецова [12], де застосовано 5-бальну систему оцінки життєздатності дерев: 5 балів (дерева без пригніченого росту 3 повноцінною листковою поверхнею); 4 бали (дерева з ростом, що загалом відповідають нормі та мають близько 20-25 \% недієвої поверхні); 3 бали (дерева 3 послабленим ростом, які мають близько 50 \% недієвої листкової поверхні); 2 бали (дерева 3 пригніченим ростом, приріст поточного росту майже відсутній; мають близько 75-80 \% недісвої листкової поверхні); 1 бал (мертві та всихаючі, без поточного приросту дерева 3 $100 \%$ недієвою листковою поверхнею).

Опис трав'яного вкриття виконували за загальноприйнятими геоботанічними методиками [27].

\section{Результати дослідження та їх обговорення}

Дубляни - селище міського типу Самбірського району Львівської області України. Сьогодні селище налічує 2160 мешканців. Згідно з розробленим генеральним планом селища [26], прогнозують зростання кількості населення до 3386 осіб та, відповідно, розвиток поселення зі збільшенням площі від 532,3 до 838,4 га.

За переказами назва села походить від дубових лісів, яких колись було багато в цій місцевості. Перша письмова згадка про Дубляни стосується 1432 року. Аж до 1772 р. село було центром адміністративного ключа, мало "двір" для збирання повинностей 3 навколишніх сіл: Дубляни, Озимина, Пруси, Биків, Дорожів, Билина, Гортиничі, Залужжя, Літиня, Грушів, Бронниця, Татари, Лужок, Якубова Воля [21]. Панський маєток розташовувався на мисі, в оточенні потічків, мав певне оборонне значення (рис. 1).

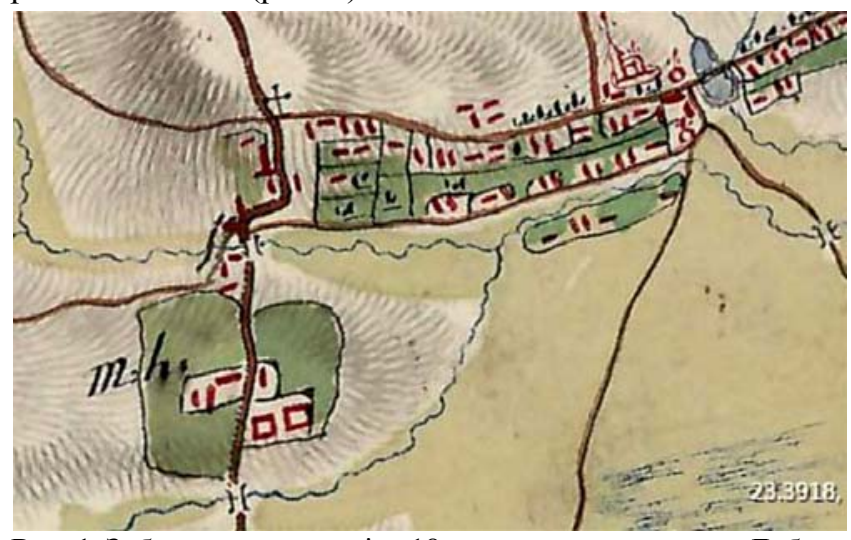

Рис. 1. Зображення на карті к. 18 ст. панського маєтку у Дублянах, який став основою створення ОПЗФ [17]

Територія проєктованого парку-пам'ятки садовопаркового мистецтва у смт Дубляни, відповідно до геоботанічного районування (Дідух, Шеляг-Сосонко, 2003), належить до Центральноєвропейської зони широколистяних лісів Свропейської широколистяно-лісової області. Розташована у межах Південнопольсько-За- 
хідноподільської підпровінції широколистяних лісів, лук, лучних степів та евтрофних боліт. Належить до Сандомирсько-Верхньодністровського округу дубових, дубово-соснових лісів, лук та евтрофних боліт. Охоплює долину верхньої частини Дністра та Сяну [7]. Лучна рослинність серед трав'яних формацій у межах басейнових систем верхнього Дністра займає панівне місце. У рівнинній частині басейну більше заплавних i менше низинних та суходільних (межирічних) лук. У передгір'ї і на схилах гір найбільше поширені післялісові суходільні луки. Болотна рослинність трапляється у межах Верхньодністерської рівнини та в долинах приток Дністра. Це болота низинного типу: осокові, осоково-гіпнові, рідше тростинові і вільхові [10].

Досліджуваний парк розташований на похилій мисовій території, з перепадом висот 2-4 м понад яроподібними долинами струмків та р. Веретено, у місцях пониження рельєфу - частково перезволожені території.

Для проведення досліджень, територію об'єкта загальною площею 4,9 га, умовно поділено на 4 ділянки (рис. 2).

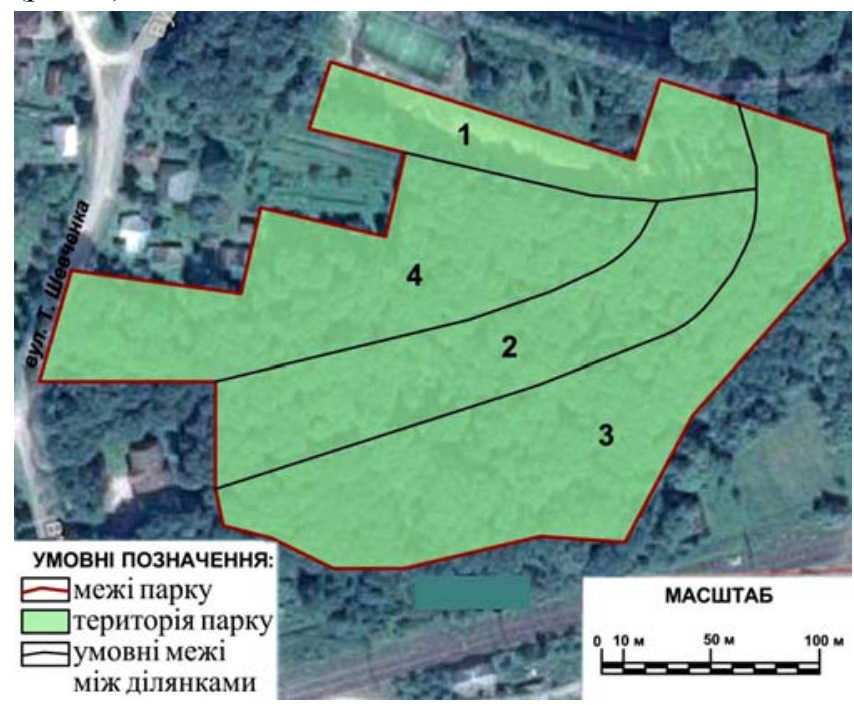

Рис. 2. Карта-схема "Дублянського парку" з умовним поділом території на ділянки

Ділянка 1. Розташована з північного боку вздовж пішохідної алеї, що розділяє футбольний стадіон та територію парку. Це зволожена територія, відмежована від парку невеликим каналом. Тут ростуть мікроугруповання: модрина європейська+клен-явір+тополя чорна+верба ламка. У підрості переважає Juglans mandshurica Маxim., Acer pseudoplatanus L., Salix $\times$ fragilis L. та $S$. al$b a$ L. Присутні напіввідкриті простори, у трав'яному вкритті яких домінують синантропні види.

Ділянка 2. Розташована вздовж головної алеї в середині парку. Межа цієї ділянки проходить по віковому грабовому боскеті (рис. 3) та зруйнованій липовій алеї (рис. 4,a). Окремими особинами вздовж алеї є солітери інтродукованих видів: Juglans nigra L. та J. mandshurica, Phellodendron amurense Rupr, Acer saccharinum L. та $A$. negundo L. У глибині ділянки поширені мікроугруповання: дуб звичайний+клен-явір+береза повисла; липа дрібнолиста+клен гостролистий; ялина європейська+береза повисла+липа дрібнолиста+черешня. У підрості переважає самосів Acer platanoides L. та A. pseudoplatanus.

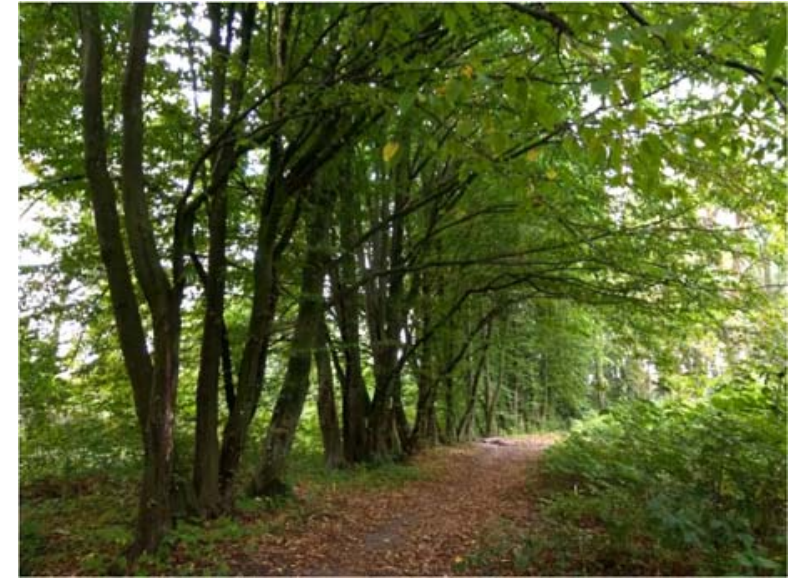

Рис. 3. Збережений грабовий боскет як елемент давнього регулярного закладення (фото Петришин Г. П., 2019)
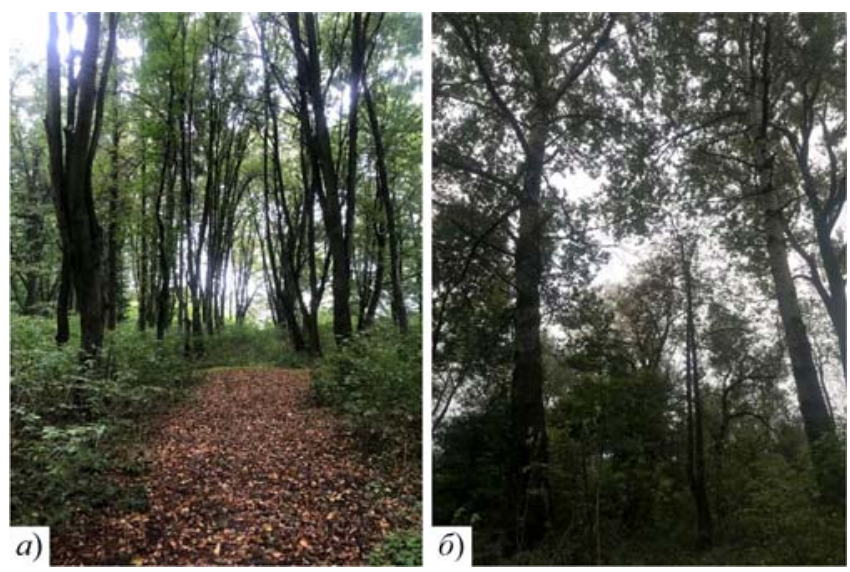

Рис. 4. Залишки липової алеї ( $a$ ) та мікроугруповання за участі Populus $\times$ canescens (б) (фото Онуфрів Я. О., 2019)

Ділянка 3. Розташована у перезволоженому гігротопі вздовж річки Веретено. Переважають мікроугруповання: тополя сіріюча+вільха чорна+тополя біла+верба ламка (рис. 4,б). На більш підвищених ділянках поширені мікроугруповання: береза повисла+в'яз голий+ клен гостролистий.

Ділянка 4. Територія, що зі заходу примикає до наявної забудови і братської могили, з півночі обмежується каналом, а 3 південного-сходу примикає до серединної зони парку. На ділянці зростають мікроугруповання: клен-явір+ясен звичайний+дуб звичайний; в'яз голий+клен-явір.

За результатами аналізу картографічних джерел та натурних обстежень встановлено, що на дослідженій території відсутні ознаки функціонального зонування, також немає проєкту організації його території. Присутній тільки один тип ландшафту - лісовий, який виник на місці порушеного паркового ландшафту. Залишились деякі елементи регулярного ландшафту у вигляді ділянки перерослого грабового боскету, які потребують реконструкції та збереження. Разом 3 тим виявлено порушені цінні рослинні угруповання лісового ландшафту - вікові групи із смереки (рис. 5), які також потребують збереження.

Об'ємно-просторова структура досліджуваного парку характеризується закритим простором. Відсутній історичний картографічний матеріал, де було б зображене планування насаджень за останнє століття. Відбувається неконтрольоване спонтанне розростання підросту деревних рослин. Відсутні повністю відкриті простори, а також налічується декілька напіввідкритих 
просторів. Напіввідкриті простори спостерігаються вздовж русла річки Веретено та алеї, що простягається вздовж північної межі парку. Відбулася повна трансформація галявин. Спостерігається зміна видових точок на окремих ділянках. Потрібне впорядкування дорожньо-стежкової мережі, структури візуальних зв'язків та композиційних акцентів із деревних рослин та малих архітектурних форм.

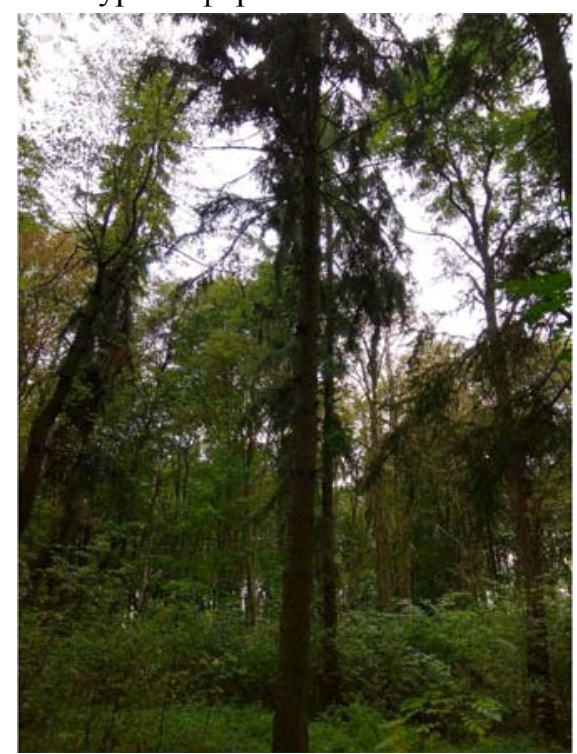

Pис. 5. Збережені вікові групи Picea abies (L.) H. Karst. (фото Петришин Г. П., 2019)

Дендрофлора. Встановлено та уточнено кількісний та якісний склад видового різноманіття дослідженої території парку у смт Дубляни, Самбірського району Львівської області. Видове різноманіття паркових насаджень $є$ надзвичайно важливою їх ознакою, оскільки визначає структуру та стратегію розвитку рослинних угруповань у конкретних умовах. У дендрофлорі дослідженого парку більшість рослин належить до відділу Magnoliophyta. На дослідженій території видовий склад дендрофлори представлений 39 видами деревних рослин, які належать до 16 родин. Найбільш репрезентативною виявилася родина Salicaceae Lindl. (шість таксонів), що пов'язано із розташуванням території парку у долині річки Веретено. Це види свіжих і вологих гігротопів. Наступними є родини Pinaceae Lindl., Betulaceae C. A. Agardh., Juglandaceae Lindl., Rosaceae Juss., Aceraceae Lindl. (по чотири таксони). Інші родини представлені одним-двома таксонами (рис. 6).

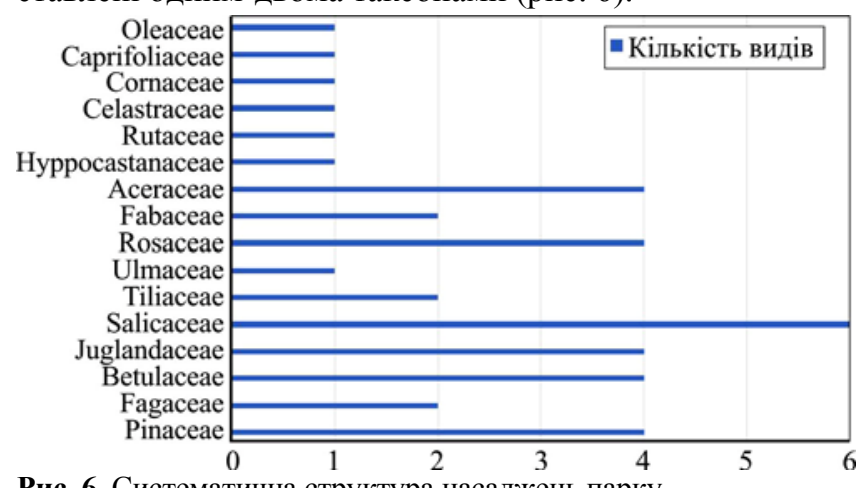

Рис. 6. Систематична структура насаджень парку

Серед життєвих форм, які формують основу цього парку, переважають дерева (30 таксонів). Кущовий ярус має різний ступінь сформованості та представлений незначною кількістю видів. Кущі представлені такими лісовими видами: Euonymus europaeus L., Cornus sanguinea L., Rosa canina L.

У складі паркового фітоценозу смт Дубляни є інтродуковані види, а саме: Juglans nigra та J. mandshurica, Phellodendron amurense, Acer sacharinum та A. negundo. За таких умов зростання для цих видів характерна досить висока стійкість. Деякі 3 них дають природне поновлення (рис. 7).

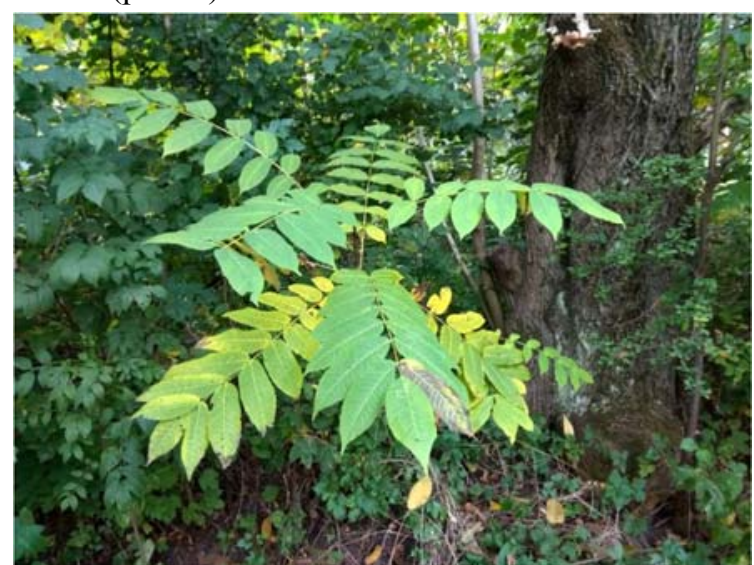

Рис. 7. Поновлення Juglans mandshurica (фото Петришин Г. П., 2019)

Під час обстежень виявлено поодинокі вікові дерева. Це названі вище екзоти (Juglans nigra та J. mandshurica, Phellodendron amurense) із обхватом стовбура від $0.6 \mathrm{~m}$; Acer sacharinum та A. negundo - із обхватом стовбура 0.9-1.4 м. Аборигенними віковими особинами є Populus nigra L., P. ×canescens та P. alba L. - обхват 1.21.4 м; Picea abies (L.) Karst.) та Larix decidua Mill. (рис. 8), обхват яких перевищує 0.7 м.
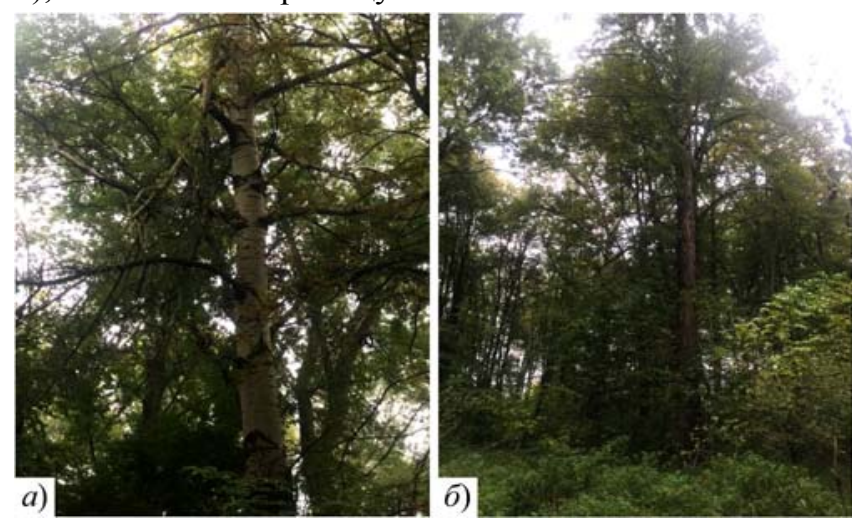

Рис. 8. Вікова Populus $\times$ canescens (Ait) Smith (а) та вікова Larix decidua у парковому фітоценозі (б) (фото Онуфрів Я. О., 2019)

Життєздатність досліджених вікових дерев оцінено на 4 та 5 балів, вони $є$ у доброму та задовільному санітарному стані. Вікові дерева, що збереглися до наших днів на території парку у смт Дубляни Самбірського району Львівської області дають певне уявлення про первинні насадження парку, хоча повністю не відображають його таксономічну структуру. Вони надають насадженням парку більшої виразності, могутності. Дерева-довгожителі мають наукову, естетичну, господарську цінність і потребують застосування заходів 3 їх охорони і консервації.

Головна відмінність паркового фітоценозу від природного полягає в антропогенному походженні та специфіці його розвитку. У процесі обстежень парку у смт Дубляни маршрутним методом виявлено, що піднаме- 
тове трав'яне вкриття густе із високим відсотком проєктивного вкриття. Вдалось зібрати і визначити понад 70 видів трав'яних рослин.

У складі трав'яних рослин здебільшого переважають лісові види Це пов'язано із тим, що це рослинне угруповання як штучне, не забезпечувалося регулярним доглядом. Найвища частота трапляння та проєктивного вкриття від 70 до $90 \%$ спостерігається у Carex brizoides L., Stellaria holostea L., Aegopodium podagraria L., Pulmonaria obscura Dumort., Galeobdolon luteum Huds. типових індикаторів природних дубових і букових лісів. Їх ценопопуляції виступають фоном трав'яного вкриття, поширюючись великими плямами (рис. 9).

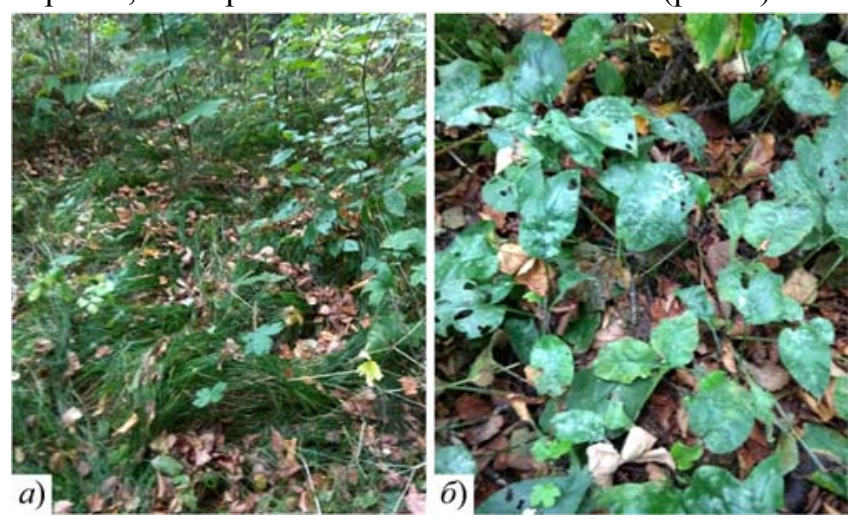

Рис. 9. Carex brizoides $(a)$ та Pulmonaria obscura у піднаметовому трав'яному вкритті (б) (фото Петришин Г. П., 2019)

Спорадично трапляються такі лісові види, як Dryopteris carthusiana (Vill.) H. P. Fuchs, Dryopteris filix-mas (L.) Schott, Polygonatum multiflorum (L.) All. На багатьох ділянках парку поширена рудеральна та сегетальна рослинність, що засвідчує антропогенний вплив.

Більшість трав'яних рослин $є$ вегетативно рухомими багаторічниками, що дає їм змогу поширюватися, захоплювати нові ділянки та утримувати своє місце у парковому угрупованні впродовж тривалого часу.

Варто зауважити, що на цю територію постійно чиниться антропогенний тиск. Не здійснюють систематичного догляду за наявними деревними насадженнями та трав'яним вкриттям. В окремих місцях виявлено механічні пошкодження стовбурів внаслідок недбалого господарювання місцевих жителів, а саме збирання березового соку навесні, всихання дерев, поширення напівпаразита Viscum album L., недостатнє забезпечення рослин елементами мінерального живлення на порушених грунтах. Спостерігається зниження декоративності, довговічності, послаблення рекреаційних та екологічних функцій зелених насаджень. Загалом деградація зелених насаджень обстеженої території спричинена сукупністю біологічних, екологічних, організаційно-правових, фінансово-економічних чинників.

\section{Висновки}

На підставі здійснених історичних, дендрологічних та флористичних досліджень та їх аналізу ми вважаємо за доцільне надати обстеженій території "Дублянський парк" статус парку-пам'ятки садово-паркового мистецтва місцевого значення. Підсумовуючи, можемо відзначити:

- в історичних документах відсутній картографічний матеріал щодо планувально-просторових особливостей запропонованої для охорони паркової території;

- під час натурних обстежень встановлено, що на дослідженій території відсутні ознаки функціонального зонування, немає проєкту організації його території;
- первісний культурний ландшафт території з плином часу трансформувався у лісовий внаслідок відсутності догляду;

- встановлено межі проєктованого парку-пам'ятки садовопаркового мистецтва місцевого значення;

- виявлено порушені вікові деревні групи із смереки та модрини європейської, які потребують збереження;

- видовий склад дендрофлори парку представлений 39 видами деревних рослин, які належать до 16 родин. Більшість рослин належить до відділу Magnoliophyta;

- серед життєвих форм, які формують основу цього парку, переважають дерева (30 таксонів). Кущовий ярус має різний ступінь сформованості та представлений незначною кількістю видів;

- особливістю насаджень парку є присутність у їх складі солітерних вікових дерев-екзотів, деякі 3 яких дають життєздатне поновлення, що свідчить про багатство видового складу та відсутність таксономічної деградації.

- вікові дерева-екзоти потребують охорони та консервації.

- у процесі обстежень парку у смт Дубляни маршрутним методом виявлено, що піднаметове трав'яне вкриття має високий відсоток (70-90 \%) проєктивного вкриття. Зібрано і визначено понад 70 видів трав'янистих рослин;

- обгрунтовано доцільність створення парку-пам'ятки садовопаркового мистецтва місцевого значення на території, запропонованій для охорони у смт. Дубляни Самбірського району.

Основними завданнями функціонування парку $\epsilon$ : збереження вікових дерев-екзотів у фітоценозах паркового ландшафту; впорядкування дорожньо-стежкової мережі, структури візуальних зв'язків та композиційних акцентів із деревних рослин та малих архітектурних форм; недопущення синантропізації та урбанізації паркових територій; залучення території парку у систему рекреаційних маршрутів Дублянської ОТГ [1].

\section{References}

1. Avtorske pravo na sluzhbovyi tvir "Proekt stvorennia parku-pamiatky sadovo-parkovoho mystetstva mistsevoho znachennia "Dublianskyi park" na terytorii smt Dubliany Sambirskoho raionu Lvivskoi oblasti ("Dublianskyi park"); Petryshyn, H. P., Tupis, S. P., Onufriv, Ya. O., Lukashchuk, H. B.; Natsionalnyi universytet "Lvivska politekhnika". Svidotstvo pro reiestratsiiu avtorskoho prava na tvir № 95649 vid 28.01.2020. [In Ukrainian].

2. Bessonova, V. P., \& Chonhova, A. S. (2013). Obiemno-prostorova struktura nasadzhen parkiv-pamiatok sadovo-parkovoho mystetstva Zaporizhzhia. Scientific Bulletin of UkrSFU, 23(9), 318-322. [In Ukrainian].

3. Denysova, H. V. (2015). Fitotsenotychna struktura palatsovo-parkovykh kompleksiv Zakhidnoho Lisostepu ta shliakhy yii optymizatsii. Abstract of Candidate Dissertation for Agricultural Sciences (06.03.01 - Forest Crops and Phytomelioration); Nats. lisotekhn. un-t Ukrainy. Lviv, 20 p.

4. Departament ekolohii ta pryrodnykh resursiv Lvivskoi oblasnoi derzhavnoi administratsii. (2008). Rehionalna tsilova prohrama rozvytku zapovidnoi spravy u lvivskii oblasti na period 2009-2020 $r r$. Retrieved from: http://deplv.gov.ua/diialnist-departamentu/zberezhennia-bioriznomanittia/regionalna-cilova-programarozvitku-zapovidnoyi-spravi-u-lvivskij-oblasti-na-period-20092020rr-2. [In Ukrainian].

5. Historic Gardens (The Florence Charter 1981) [Date of application: 21.05.1981]. International Council on Monuments and Sites. Retrieved from: http://www.international.icomos. org/charters/ gardens_e.pdf.

6. Instruktsiia $\mathrm{z}$ tekhnichnoi inventaryzatsii zelenykh nasadzhen $\mathrm{u}$ mistakh ta selyshchakh miskoho typu Ukrainy (Nakaz Derzhkomitetu budivnytstva, arkhitektury ta zhytlovoi polityky Ukrainy $\mathrm{N}$ 226 vid 02.12.2001 r.). Retrieved from: http://zakon4.rada.gov.ua/laws/show/z0182-02. [In Ukrainian].

7. Kalinovych, N., Senchyna, B., Tasienkevych, L., \& Nazaruk, M. (Ed.). (2018). Roslynnyi pokryv oblasti. Lvivska oblast: pryrodni 
umovy ta resursy. Lviv: Vyd-vo Staroho Leva, 230-258. [In Ukrainian].

8. Kilinska, K. Y., Skutar, T., Lopushniak, L., \& Palamar, D. (2013). Parky - pamiatky sadovo-parkovoho mystetstva Chernivetskoi oblasti - obiekty rekreatsiinoho pryrodokorystuvannia. Heohrafiia ta turyzm. Kyiv: Alter-Pres, 138-151. [In Ukrainian].

9. Klymenko, Yu. O. (2010). Zminy nasadzhen starovynnykh parkiv-pamiatok sadovo-parkovoho mystetstva Vinnytskoi oblasti. Ukrainskyi botanichnyi zhurnal: nauk. Zhurnal NAN Ukrainy, 67(2), 200-207. [In Ukrainian].

10. Kovalchuk, I. P. (Ed.), \& Pylypovych, O. V. (2017). Heoekolohiia richkovo-baseinovoi systemy verkhnoho Dnistra: monohrafiia. Lviv. Kyiv: LNU imeni Ivana Franka, 284 p. [In Ukrainian].

11. Kurnytska, M. P., Parkhuts, L. V., \& Horbenko, N. Ye. (2019). The landscape and historic analysis of the park territory of Pomoryany village. Scientific Bulletin of UNFU, 29(9), 32-37. https://doi.org/10.36930/40290905

12. Kuznietsov, S. I., $\quad$ Levon, F. M., $\quad$ Klymenko, A. Yu. Pylypchuk, V. F., \& Shumyk, M. I. (2000). Suchasnyi stan ta shliakhy optymizatsii zelenykh nasadzhen $\mathrm{v}$ Kyievi. Introduktsiia $i$ zelene budivnytstvo: zb. nauk. prats, 12, 90-104. [In Ukrainian].

13. Ławniczak, Gr. (2014). Analiza przestrzenno-historyczna założenia pałacowo-parkowego w Żydowie gm. Rokietnica, pow. poznański. Wartości zabytkowe rewaloryzowanego obiektu uzasadnieniem wniosku o sporządzenie planu przestrzennego miejscowości. Teka Kom. Arch. Urb. Stud. Krajobr. OL PAN, 2014, $\mathrm{X} / 4,48-62$.

14. Michałowski, A. (2010). Rewaloryzacja ogrodu Jana Klemensa Branickiego w Białymstoku na tle działań konserwatorskich w ogrodach historycznych Europy, [w:] Parki i ogrody zabytkowe, ochrona i konserwacja, Ogród Branickich w Białymstoku, historia rewaloryzacji, Białystok. [In Poland].

15. Mitkowska, A. (2012). Rozważania o wartościowaniu ogrodów zabytkowych dla ich ochrony i konserwacji, [in:] Wartościowanie w ochronie i konserwacji zabytków, (Ed.) B. Szmygin, Wydawnictwo Politechniki Lubelskiej, PKN ICOMOS, Lublin, 121-134. [In Poland].

16. Moroz, P. I. (2006). Rekonstruktsiia zanedbanykh parkiv yak zasib pokrashchennia landshaftnykh ta estetychnykh yakostei yikh obiektiv. Starovynni parky i botanichni sady - naukovi tsentry zberezhennia bioriznomanittia ta okhorona istoryko-kulturnoi spadshchyny: mater. mizhnar. nauk. konf., 357-362. Kyiv: Akademperiodyka, 460 p. [In Ukrainian].

17. Petryshyn, H. P. (2006). "Karta F. fon Miga" (1779-1782 rr.) yak dzherelo do mistoznavstva Halychyny. Lviv: Vyd-vo Nats. un-tu "Lviv. politekhnika", 292 p. [In Ukrainian].

18. Popovych, S. Yu., Syplyva, N. O., \& Korinko, O. M. (2012). Kultyvovana dendroflora parkiv-pamiatok sadovo-parkovoho mystetstva Vinnychyny: monohrafiia. Kyiv: Vyd-vo "Fitosotsiotsentr", 162 p. [In Ukrainian].

19. Reshetyuk, O. V. (2017). The prospect of using natural reserve fund parks in bukovyna for its biodiversity enrichment. Scientific Bulletin of UNFU, 27(10), 42-50. https://doi.org/10.15421/40271006

20. Rozporiadzhennia Kabinetu Ministriv Ukrainy "Pro skhvalennia Kontseptsii Zahalnoderzhavnoi prohramy rozvytku zapovidnoi spravy na period do 2020 roku" [Chynnyi; Pryiniattia vid
08.02.2006]. No 70-r. Kyiv. Retrieved from: https://zakon.rada.gov.ua/laws/show/70-2006-r. [In Ukrainian].

21. Sambor. (1880). Słownik geograficzny Królestwa Polskiego i innych krajów słowiańskich. Vol. 1: [Aa - Dereneczna] Red.: Chlebowski, B., Sulimierski, F., \& Walewski, W. Warszawa, 960 p. [In Poland].

22. Serebriakov, I. G. (1962). Ekologicheskaia morfologiia rastenii: Zhiznennye formy pokrytosemennykh i khvoinykh. Moscow: Publishing Vyssh. shkola, 324 p. [In Russian].

23. Sosnova, N. S. (2003). Arkhitekturno-landshaftnyi uklad sadybno-parkovykh kompleksiv Halychyny (kintsia XVIII - pochatku KhKh stolit). Abstract of Candidate Dissertation for Architectural Sciences (18.00.01 - Architecture theory, restoration of architectural monuments). NU "Lvivska politekhnika". Lviv, 20 p. [In Ukrainian].

24. Spysok latynskykh nazv roslyn podano za The Plant List. (2020). [Date of application: 02.10. 2020]. Retrieved from: www.theplantlist.org. [In Ukrainian].

25. Tupis, S. P. (2019). Metody zberezhennia ta vykorystannia obiektiv pryrodno-zapovidnoho fondu u strukturi mist. Abstract of Candidate Dissertation for Architectural Sciences (18.00.01 - Architecture theory, restoration of architectural monuments). NU "Lvivska politekhnika". Lviv, 24 p. [In Ukrainian].

26. TzOV "In-t heoinformatsiinykh system". (2012). Heneralnyi plan smt. Dubliany Sambirskoho raionu Lvivskoi oblasti. Hrafichni materialy, Lviv. [In Ukrainian].

27. Yakubenko, B. Ye., Popovych, S. Yu., \& Ustymenko, P. M. (2016). Heobotanika: pidruchnyk. Kyiv: Vyd-vo "Fitosotsiotsentr", 357 p. [In Ukrainian].

28. Yavorska, O. H. (Ed.). (2005). Zapovidni obiekty Vinnychchyny. Vinnytsia: VELES, 104 p. [In Ukrainian].

29. Zakon Ukrainy "Pro ekolohichnu merezhu Ukrainy" [Chynnyi vid 24.06.04; Redaktsiia vid 19.04.2018]. Information of the Supreme Council of Ukraine (VVR). (2004) No 45, article 502. Retrieved from: https://zakon.rada.gov.ua/laws/show/1864-15. [In Ukrainian].

30. Zakon Ukrainy "Pro okhoronu navkolyshnoho pryrodnoho seredovyshcha" [Chynnyi vid 26.06.1991; Redaktsiia vid 12.10.2018]. Information of the Supreme Council of Ukraine (VVR). (1991) No 41, article 546. Retrieved from: https://zakon.rada.gov.ua/laws/show/1264-12. [In Ukrainian].

31. Zakon Ukrainy "Pro osnovni zasady (stratehiiu) derzhavnoi ekolohichnoi polityky Ukrainy na period do 2030 roku" [Chynnyi; vvedennia v diiu vidbudetsia 01.01.2020; Pryiniattia vid 28.02.2019]. Information of the Supreme Council of Ukraine (VVR). (2019) No 16, article 70. Retrieved from: https://zakon.rada.gov.ua/laws/show/2697-19. [In Ukrainian].

32. Zakon Ukrainy "Pro pryrodno-zapovidnyi fond Ukrainy" [Chynnyi vid 16.06.92; Redaktsiia vid 19.04.2018]. Information of the Supreme Council of Ukraine (VVR). (1992) No 34, article 502. Retrieved from: https://zakon.rada.gov.ua/laws/show/245612. [In Ukrainian].

33. Zakon Ukrainy "Pro vnesennia zmin do deiakykh zakoniv Ukrainy shchodo povnovazhen $\mathrm{v}$ haluzi okhorony navkolyshnoho pryrodnoho seredovyshcha" [Chynnyi vid 19.04.2018]. Information of the Supreme Council of Ukraine (VVR). (2018) No 17, article $152 . \quad$ Retrieved from: https://zakon.rada.gov.ua/laws/show/2362-19. [In Ukrainian].

\section{SUBSTANTIATION OF THE NATURAL VALUE OF THE "DUBLIANSKY PARK" TERRITORY IN ORDER TO GRANT THE STATUS OF A PARK - MONUMENT OF GARDEN AND PARK ART}

A representative and functionally integrated network of territories and objects of the nature reserve fund, created taking into account scientifically substantiated approaches to the preservation of regional biotic and landscape diversity, is a structural and functional basis for the formation of the ecological network. An important element of the cultural landscape of Prykarpattia, Dubliansky Park in Dubliany village, Sambir District, Lviv Region is studied. According to the results of the cartographic sources analysis and field surveys, it was determined that there are no signs of functional zoning in the study area, and there is no project for the organization of its area. There is only one type of landscape - forest, which arose on the site of the disturbed park landscape. At the same time, disturbed valuable plant groups of the forest landscape (European spruce groups, etc.) were found. There are some elements of the re- 
gular landscape in the form of an area of overgrown hornbeam, which need reconstruction and preservation. There is no historical cartographic material, which would depict the planning of plantations in the last century. In the study area, the species composition of dendroflora is represented by 39 species of woody plants belonging to 16 families. The most representatives were from the family Salicaceae Lindl. (six taxa), which is due to the location of the park in the valley of the river Vereteno. These are types of fresh and moist hygrotopes. The bush tier has varying degrees of formation and is represented by a small number of forest species such as Euonymus europaeus L., Cornus sanguinea L., Rosa canina L. As part of the park phytocenosis of Dubliany village there are introduced species, namely: Juglans nigra L. and J. mandshurica Maxim, Phellodendron amurense Rupr, Acer sacharinum L. and A. negundo L. Under these growing conditions, these species are characterized by a fairly high resistance. Some of them give a natural renewal. The peculiarity of Dubliansky Park plantations is that they contain age-old exotics, represented by single individuals. Age-old trees that have survived to this day in the park give some idea of the original plantings of the park, although they do not fully reflect its taxonomic structure. Age-old exotics need protection and conservation. The composition of herbaceous plants is mostly dominated by forest species. The highest frequency of occurrence and projective cover is observed in Carex brizoides L., Stellaria holostea L., Aegopodium podagraria L., Pulmonaria obscura Dumort., Galeobdolon luteum Huds. The expediency of creating a park-monument of garden and park art of local significance on the territory proposed for protection in Dubliany village, Sambir District, Lviv Region is substantiated. The boundaries of the projected park-monument of landscape art of local significance have been established. The main tasks of the park are as follows: preservation of age-old exotic trees in the phytocenoses of the park landscape; maintaining the ecological balance of the region; prevention of synanthropization and urbanization of park areas disturbed by human activities; development of recreation in Dubliany United Territorial Community.

Keywords: park-monument of garden and park art; forest landscape; Pre-Carpathian landscape; dendroflora, grass cover. 